Beyond 'aam in Ethiopia:

a short Note on an Arabic-Islamic Collection of Texts written in Ethiopian Script (fidäl)

Gori, Alessandro

Published in:

Creating Standards.

DOI:

10.1515/9783110639063-012

Publication date:

2019

Citation for published version (APA):

Gori, A. (2019). Beyond 'aam in Ethiopia: a short Note on an Arabic-Islamic Collection of Texts written in Ethiopian Script (fidäl). In D. Bondarev, A. Gori, \& L. Souag (Eds.), Creating Standards. : Interactions with Arabic script in 12 manuscript cultures (pp. 297-312). De Gruyter. Studies in Manuscript Cultures Vol. 16 https://doi.org/10.1515/9783110639063-012 


\title{
Beyond 'ağamī in Ethiopia: a short Note on an Arabic-Islamic Collection of Texts written in Ethiopian Script (fidäl)
}

\begin{abstract}
As in many other countries in Sub-Saharan Africa, Muslims in Ethiopia have produced a substantial amount of literature in their local languages, mostly using the Arabic script rather than the Ethiopic syllabary (fidäl), which has been connected with the Ethiopian Christian Church and state for centuries. Recently, after fidäl was adopted to write the language of the Harari Muslim people, a manuscript was written in which texts in Arabic and Old Harari were copied in Ethiopic script. I have analysed the manuscript in this paper, highlighting the strategies that the copyist followed in order to transcribe Arabic into fidäl, and have attempted to place the work within the general framework of Islamic-Christian relationships in Ethiopia.
\end{abstract}

\section{Fidäl, Arabic and Islamic languages in Ethiopia: sketching a framework}

The usage of the Ethiopian script (fidäl) ${ }^{1}$ to write Arabic and other 'Islamic languages' of the Horn of Africa ${ }^{2}$ is not completely unknown, but has so far been scarcely documented and analysed. While it is actually a relatively rare phenomenon, it does deserve some attention, as its study could be of some interest for linguists (particularly sociolinguists) and more generally for researchers investigating the social and cultural history of the Muslims of the Horn of Africa.

The data presented in this paper were compiled within the framework of and thanks to the research project 'Islam in the Horn of Africa: a Comparative Literary Approach' (IslHornAfr, European Research Council Advanced Grant 322849).

1 For a first introduction to Ethiopian script, see Frantsouzoff 2010.

2 I use the concept of 'Islamic languages' here in a very loose way as a generic term to refer to languages spoken (also) by Muslims and with no intention to touch on the issues discussed by Bausani 1967, 1978, 1981, Brenner and Last 1985, Zappa 2004, 2009 and Gori 2015.

Ә Open Access. (C) 2019 Alessandro Gori, published by De Gruyter. (c) BY-NC-ND This work is licensed under the Creative Commons Attribution-NonCommercial-NoDerivatives 4.0 License. 
Some marginal paratexts among Christian Ethiopian manuscripts in Gə‘əz and Amharic have been found to include Arabic words, sentences and also short fully-fledged texts written in Ethiopian and/or in Arabic scripts. ${ }^{3}$ Christian Ethiopian astronomical and calendar treatises (e.g. the Bahrä hassab, 'The sea of calculation'), ${ }^{4}$ contain many Arabic words and expressions. In the famous $16^{\text {th }}$ century Christian treatise Anqașä amin (the 'Door of the faith'), written in Gə‘əz, Arabic-Islamic religious terms are quoted and transcribed using fidäl script. ${ }^{5}$ Also, the $20^{\text {th }}$-century Amharic Christian Sylloges of šayh Zäkaryas contain several words and phrases taken from Arabic. ${ }^{6}$ During my recent examination of MS EMML 6239, I identified a bilingual Arabic-Amharic version of šayh Zäkaryas' work written entirely in Ethiopian fidäl. ${ }^{7}$ Arabic-Islamic words are also scattered throughout Christian Ethiopian magical literature, where they function as 'abracadabra' to enhance the mystical power of the texts. ${ }^{8}$ The writing down of Islamic texts in Arabic or Amharic or their transliteration into one of these languages was usually carried out by or for the sake of Western scholars working in Ethiopia. ${ }^{9}$

3 Examples can be found among the manuscripts catalogued by the Hill Monastic Manuscript Library in Collegeville, MN, USA in the Ethiopian Manuscript Microfilm Library (EMML). See for example in MSS EMML 1056 fols 171b-174a (Gə‘วz equivalent of Turkish and Arabic words); 1105 fol. 129b (name of Mary in Arabic); 1187, fol. 73b and 74a (names of the months in Arabic); 1168 2a (Arabic numerals); 1419 fol. 42b (Arabic names of the stars and of the months); 1373 fol. $1 \mathrm{~b}$ and recto of the last rear guard leaf (exercising in Arabic); 1599, last rear guard leaf (Arabic numerals); 2011, fol. 72a (Arabic prayer in Ethiopian letters); 2054, fol. 247a (note in Arabic and Gə‘əz); 2436, fol. 160a (prayers in Arabic written in Ethiopian letters); 2531, fol. 175b (explanation of Arabic and Hebrew words); 2548, fol. 4a (name of Mary in various different languages); 2630, fol. 165b (name of Mary); 3127, fol. 174b (pen trial); 4036, fol. 4b (theological formula ArabicAmharic); 4836, fol. 78b (unreadable note); 4909, fol. 145b and fol. 149a (stamp of nəguś Mika'el of Wällo); and 4922 fol. $1 \mathrm{~b}$ (a holy image printed in some Arab country).

4 Pietruschka/Amha Asfaw/Getatchew Haile 2003.

5 The Anqașä amin is a polemical work written by Bnbaqom a learned Muslim man who converted to Ethiopian Orthodox Christianity in the first half of the $16^{\text {th }}$ century and subsequently wrote a defence of the Christian faith also using verses from the Qur'ān. The Ethiopic Anqașä amin text was edited (and translated into French) by Emeri van Donzel in 1969. For an analysis of the Arabic passages, see especially van Donzel 1969, 39-43.

6 On the Sylloges of šayh Zäkaryas, see Gori 2001 and Gori 2003. On the author, a learned Muslim man (c. 1845-1920), who converted to Christianity towards the end of the $19^{\text {th }}$ century, see Gori 2014a. 7 I gave a presentation on this text at the Colloque Manuscrits chrétiens et islamiques d'Ethiopie (XIIIe-XXe siècle) in Paris on Dec. 122014 (see Gori 2014b).

8 A remarkable example of a magical prayer made up of passages of the Qur'ān is discussed by Marcel Griaule (see Griaule 1930, 109-110).

9 For example, see the texts published by Enrico Cerulli in 1926; and the collection of Qur'ānic 
Moving from the Ethiopian Christian to the Ethiopian Islamic cultural landscape, the existence of Arabic-Islamic texts written in fidäl becomes less vague, at least during the modern era. A cultural and religious prejudice identifying Ethiopian script with Ethiopian Christianity may have hindered the usage of fidäl among Muslims at an early stage. However, since the mid-20 $0^{\text {th }}$-century emergence of Islamic books printed in Amharic and Tigrinya, Ethiopian script has also begun to be used to write scattered words and phrases in Arabic. After the fall of the Socialist regime in 1991, a more or less religiously oriented Muslim book production began to blossom in Ethiopia, and fidäl became more and more widespread among Amharic- and Tigrinya-speaking Muslims who make use of it to transliterate passages from the Qur'an, Hadith and other fundamental texts of the Islamic tradition for books and booklets published in local languages. The subsequent birth and diffusion of a kind of Islamic calligraphic practice in Ethiopian script came to confirm a fairly generalised acceptance of fidäl among many Ethiopian Muslims.

An especially remarkable position in the general picture I am sketching here is occupied by Harari, the Semitic language of the city of Harar, spoken by the ethnic group of the Hararis. Traditionally written in Arabic script since at least the beginning of the $18^{\text {th }}$ century, ${ }^{10}$ Harari texts written in Ethiopian script have been found to have emerged at the end of the $19^{\text {th }}$ century, after the walled city was conquered by Mənilək in 1887 and incorporated into the modern Ethiopian state. ${ }^{11}$ The connection between the Ethiopian writing system and the Harari language became even tighter after the fall of the Imperial state (1974) and under the Socialist regime. Harari texts in Ethiopian alphabet were published abroad $^{12}$ and

passages compiled by aläqa Tayyä for Eugen Mittwoch in Berlin who published them in 1906 in Ethiopian script.

10 For a general description of Harari literature in Arabic script, see Banti 2005, 2010. The language of the texts written in Arabic script has been labelled 'Old Harari', because it shows some quite substantial differences from modern Harari as spoken and written in Harar nowadays.

11 See for example the texts written by the secretary of ras Mäkwännən for Casimir MondonVidailhet and published by Carlo Conti Rossini in 1919 (see Wagner 2004, 355, note 5 with other examples).

12 See for example the Suwār malasāyā čč țaba ('Voice of the revolutionary youth'), a handwritten ideological journal produced by the Harari Students' Association in Egypt (Harari ardāwigā čč ahadənnat mugād misrābe). On a website entitled Everything Harar (http://www.everythingharar.com; last accessed 04/02/2018), which is run by Harari individuals from the Diaspora, I found two issues of the periodical (vol. 3 no. 2, January 1980 and vol. 3 no. 3 [originally 2], February 1980) which I was able to retrieve and download. The periodical was apparently produced in Egypt, but no information is available or traceable about its origin and periodicity. The content of the texts is extremely interesting from both a politico-cultural and from a purely linguistic point 
in Ethiopia, ${ }^{13}$ fostering the diffusion of fidäl among Hararis (first and foremost among the intellectual elite).

After the pro-Soviet regime collapsed in 1991, a relatively short period of incertitude followed: different options (Latin, Arabic, and Ethiopian scripts) for the writing of the Harari language were discussed, until eventually the choice officially fell on fidäl. ${ }^{14}$ The appearance in 1992 of the first Harari-Amharic dictionary published entirely in fidäl paved the way to further development of the connection between the Harari language and the Ethiopian script. ${ }^{15}$

Fidäl is nowadays well established among Harari speakers and readers and has progressively become more deeply rooted in the writing and reading practices and in the literary production of Hararis. At the same time, Latin script has not completely been entirely abandoned and still seems to be quite widespread among Hararis living outside Ethiopia, ${ }^{16}$ and it is extensively used on the web. ${ }^{17}$

What was probably also instrumental in this impressive success of the Ethiopian script among the Hararis was the diffusion of Amharic in the city of Harar and especially in the Harari diaspora. Numerically substantial and economically lively communities of Harari speakers can be found in Addis Ababa, Dire Dawa and many other cities of Ethiopia. These scattered groups of Hararis (in particular those living in the capital) are more and more exposed to Amharic, are practically bilingual and tend to use written Amharic for their daily business and in connection with official and bureaucratic issues. The combined effect of the shift

of view. In January 1986, the first issue of another magazine, Šahan ('The ray'), was published in fidäl in Rome by the Harargey tārih-wā āda dafdafti mugad ('Society for the research on Harari history and customs'). This periodical was subsequently transferred to Toronto (see Wagner 2003a, 6-7 and Wagner 2004, 355, note 6).

13 One example is the magazine Aner ('Make it beautiful'), published by the Harari Cultural Association of Dire Dawa with an uncertain periodicity since 1988. According to Wagner 2003a, 1, the first two issues (Sept. 1988 and Oct. 1988) were written in Arabic script. On the internet portal Everything Harar, I found a later issue (probably issue no. 2, 1990) produced in Ethiopic script.

14 For the cultural (and political) background of this decision, see Gibb 1998, 256-7 and 266, note 18. The first issue of Harari tabāa, the official newspaper of the Harari National League, was published in Hədar 1984 CE (= November-December 1991). This event might be considered a sort of official endorsement of the adoption of the Ethiopian script by the officials of the Harari regional state.

15 Abdurahman Mähamäd Qorram 1984 CE (= 1992).

16 It is estimated that one-third of the Harari people live outside Ethiopia. The most conspicuous Harari communities are now living in Australia, Canada and the USA (see Gibb 2002).

17 It must be noted that, since the Roman keyboard is surely the most widespread on computers, Amharic and Tigrinya written on the Internet often use a very simplified transliteration system based on the Latin script. This writing practice has not so far been studied by scholars of Ethiopian languages. 
to fidäl to write Harari and the wider and more intense exposure to Amharic has reduced the knowledge and usage of Arabic script among the Harari people and the knowledge of Arabic itself.

As a matter of fact, while Arabic is known as a language of culture by a very restricted circle of learned men and is used as a spoken medium of communication by Harari emigrants returning from jobs in the Gulf, the usage of Arabic script to write Harari seems to be vanishing completely. Moreover, the capability to read and understand traditional Old Harari texts written in Arabic script is apparently declining dramatically. Manuscripts in Arabic script (both in Arabic and in Old Harari language) are not copied anymore but are substituted by computer-typed books and electronic documents. The recent production of fidäl reprints of the Kitāb al-farā'iḍ ('The book of obligations'), probably the most famous piece of Harari literature, proves the sorely felt need for editions of traditional texts targeting the growing number of readers who are unable to read Arabic script. ${ }^{18}$ It is this general sociolinguistic framework which forms the context for the origin of the manuscript I am going to deal with in the rest of this chapter.

\section{Arabic in fidäl: the case of a Harar manuscript}

The manuscript I am about to discuss was photographed in Harar on 21 September 2003 by Dr Simone Tarsitani (Durham University) ${ }^{19}$ during an ethno-musicological research mission he was conducting. The item is basically a collection of different texts written down by the late Mr Abdi Abubakar Sufiyan ${ }^{20}$ with a blue ballpoint pen (some parts are in red) on a personal organiser $(15 \mathrm{~cm} \times 20 \mathrm{~cm})$ for the year 1990 of the Ethiopian Calendar (i.e. year 1997-1998 of the Gregorian calendar; the Ethiopian year starts on 11 September). The manuscript pages lack proper numeration, therefore in the following I will locate the texts according to

18 For some general information about the Kitāb al-farā'id, see Wagner 2005; the text has been published under the title Kitabul fara'id in Ethiopian script in Dire Dawa at Khaläf Mattämiya bet (i.e. printing press) s.d. The PDF of the text can be downloaded from. Everything Harar at http:// www.everythingharar.com (last accessed 05/02/2018).

19 I am very grateful to Dr Tarsitani for providing me with the images of the manuscript and for authorising me to study them. I would also like to acknowledge his generosity in providing me with all the information in his possession about the origin of the manuscript.

20 Mr Abdi Abubakar Sufiyan was actively involved in the devotional practices at the sanctuary of Aw Basor in Harar and made many efforts to keep the tradition of the Mawlid recitation alive for the benefit of the new generation. The origin of the present manuscript in fidäl can be found in the context of Mr Abdi's cultural and religious activities (personal communication from Dr Tarsitani). 
the dates shown on the daily agenda (every single page is devoted to a different day, except for the weekends: Saturdays and Sundays share the same page).

The texts are written almost continuously from the first day of the year (11 September) until 6 April. The rest of the organiser is blank, except for the pages of 4 September and 8 September (the pages in between these two dates have been torn out) and the page of the weekend 9-10 September (the last two days of the Ethiopian year). The manuscript contains texts in three languages written in Ethiopian script: Old Harari, Arabic and Oromo. Besides, English in Latin script and Arabic in Arabic script (8 September, sūrat al-kahf, Qur'an 18, verses 1-10) are also copied in the agenda.

The texts copied into the manuscript belong to what I have elsewhere referred to as the 'Harari Mawlid collection' ${ }^{21}$ that is, the constellation of poetical and prose texts (mainly in Arabic, but interspersed with sustained wide sections in Old Harari) which is usually recited by Hararis to solemnise the feast of the birthday of the Prophet and on other important public and private occasions of a religious but sometimes also a secular nature. The collection appears in a wide diffusion of manuscripts (both relatively ancient and very recent) in Ethiopia.

While no comprehensive analysis of the manuscript tradition of the 'Harari Mawlid collection' has as yet been carried out, the following data are available:

In the library of the Institute of Ethiopian Studies at the University of Addis Ababa, the following eight manuscripts contain the 'Harari Mawlid collection': 264:2, 273:3, 1855:2, 2662:23, 2663:2, 2664:2 (incomplete), 2665:2, 2666:2 (see Gori and others 2014 under the relevant entries). The Abdallah Sharif private museum in Harar ${ }^{22}$ keeps 16 codices of the 'Harari Mawlid collection':23 1435 Abdulahi Collection 93 (not dated, but certainly $20^{\text {th }}$ century); 1436 Abdulahi Collection 94 (not dated, but certainly 20 $0^{\text {th }}$ century); 1437 Abdulahi Collection 95 (not dated, but certainly post-1974); 1439 Abdulahi Collection 97 (not dated, possibly $18^{\text {th }}$ century); 1440 Abdulahi Collection 98 (dated 1395/1975); 1441 Abdulahi Collection 99 (not dated, but certainly post-1972); 1442 Abdulahi Collection 100 (not dated, possibly $19^{\text {th }}$ century); 1443 Abdulahi Collection 101 (not dated, possibly $18^{\text {th }}$ century); $1527 \mathrm{Abdu}$ lahi Collection 185 (dated 29 May 1918); 1528 Abdulahi Collection 186 (dated 1142/1729-30); 1529 Abdulahi Collection 187 (dated 9 July 1875); 1569 Abdulahi Collection 227 (not dated, possibly $20^{\text {th }}$ century); 1576 Abdulahi Collection 234 (not dated, possibly $19^{\text {th }}$ century); 1690

21 See Gori 2010 for a first description of the structure of the collection.

22 www.unesco.org/new/en/culture/themes/dynamic-content-single-view/news/opening_of_ the_permanent_exhibition_of_the_sherif_harar_city (last accessed, 06/02/2018).

23 References are given according to the current provisional numbering used for PDF files realised in May 2011 by Jeremy Brown within the framework of the Ethiopic Manuscript Imaging Project directed by Professor Steve Delamarter, to whom I am very grateful for allowing me to study the items. 
Abdulahi Collection 348 (not dated, but certainly before 1810); 1691 Abdulahi Collection 349 (not dated, but $20^{\text {th }}$ century); 1692 Abdulahi Collection 350 (not dated, but $20^{\text {th }}$ century).

The 'Harari Mawlid collection' has also been printed several times both abroad and in Ethiopia.

In Egypt, the work has been printed twice: in 1350/1931 (127 pages) and in 1366/1947 (100 pages), under the title Mawlid šaraf al-'ālamīn ('The birth of the honour of the universe'). Two editions published in Ethiopia (around 1992-1993 and in 2000) under the title Kitāb 'unwān al-šarif bi-al-mawlid al-šarif ('The book of the noble title on the noble birth') are actually photomechanical reproductions of two manuscripts. The 1992 edition (160 pages) contains a manuscript dated 1412/1992-1993 and written by an anonymous copyist. The 2000 edition (171 written pages) reproduces a manuscript dated 26 ramaḍān 1421/22 December 2000 and written by the famous copyist Ibrāhīm Muhammad Wazīr. A third Ethiopian printed edition was published in Dire Dawa at an unknown date with the title Mawlid šaraf al-'ālamīn ('The birth of the honour of the universe') at the expenses of Mahdi hāăğ 'Abdallāh. It seems to be a reprint of one of the above-mentioned Egyptian books. Finally, in ša'bān 1426/September 2005, a computer-typed text (175 pages) was circulated in Addis Ababa under the title Kitāb mawlid šaraf al-'álamin ('The book of the birth of the honour of the universe') by the Harari scholar Abū Bakr Tāabit (Sabit).

This conspicuous number of testimonies proves the high esteem that the text collection enjoys among Hararis both inside and outside the city of Harar; however, despite this, research on the origins and the first diffusion of this text collection is still scanty and insufficient. ${ }^{24}$

One of the most remarkable features of the 'Harari Mawlid collection' is that while it is structured according to a relatively stable general framework, the verses and prose sections which actually make up the textual constellation and the sequence in which they are put together show a high degree of variation from manuscript to manuscript and from book to book.

Among the testimonies of the 'Harari Mawlid collection' I am aware of I was not able to identify a direct model for the manuscript I present here.

Moreover, for the specific purposes of this chapter, I will only focus here on a number of main Arabic texts which I managed to identify, leaving to another occasion a full description of the unknown or unidentified Arabic texts and the analysis of the Oromo and Harari sections.

24 In addition, the very famous and somewhat controversial Harari scholar 'Abdallāh al-Hararī (d. 2008) realised an abridged version of it (muhtașar) and published it at an unknown date in Beirut at the Dār al-mašāri` (the publishing house of the so-called Ahbash movement). 
When lacking a well-established title, poetic texts are identified by their incipit; for cross-reference, I will use the September 2005 edition of the 'Harari Mawlid collection'.

Here is a list of the texts I managed to identify in the fidäl-Arabic part of the manuscript:

- 6-8 October: poem Ṭuf bi-hāāī ('Walk around my tavern');'

- 8-9 October: prayer for the Prophet and šayh Abādir; incipit: Șalātun wa-taslīmun wa-azkā taḥiyyatin 'alā Aḥmad al-muhtār țaha al-mafāhnir ('Peace, greeting and best salutations to Ahmad, the chosen, the possessor of the glorious deeds'); tawassaltu bi-šayh al-Abādir ('I ask the intercession of šayh Abādir'); ${ }^{26}$

- 10-14 October: poem Hâadì al-'īs adrik ka’s al-hanā' ('O Camel Driver, get the chalice of happiness'); ${ }^{27}$

- 15 October, first part of the page: poem Hud yaminan ('Take a right hand') attributed to the renowned Yemenite mystic master 'Abdallāh Ibn 'Alawī al-Haddād (1634-1720);

- 21 October (second part of the page)-27 October: poem on different epithets of the Prophet along a model structure: - [Muhammad who is] șāhib al-X [possessor of something, in an iḍāfa construction], e.g. $1^{\text {st }}$ line: Șāhib al-mu'ǧizāt al-qāti'āt ('The possessor of the irrefutable miracles'; $2^{\text {nd }}$ line: Șāhib al-barāhīn al-sāți'a 'Possessor of the clear proofs'); ${ }^{28}$

- 27-28 October: Asmā' allāh al-ḥusnā ('The beautiful names of God');

- 6-7 November: hymn in praise of the Prophet; incipit Ya wağha al-dīni wa-alkaram ( $\mathrm{O}$ face of the religion and of the generosity);

25 Mawlid edn 2005, 12-13; attributed to 'Abd al-Qādir al-Ǧīānī. The text of the poem as preserved in the 'Mawlid collection in Harar' is different from that usually featured in 'Abd al-Qādir's Dīwān (see e.g. al-Ǧìlānī s.d: 157-164).

26 Mawlid edn 2005, 124-5; šayh Abādir is the patron saint of Harar and the most revered holy man in the city (for a general introduction to his personage, see Wagner 2003b). A tahmins of the text is published in Wagner 1975, 47-53.

27 Mawlid edn 2005, 84-93. Tašțīr (possibly produced by an unknown 'Abdallāh b. Ǧa'far al'Alawī al-Yamanī) based on the poem Inna lam'a al-barq min hayfi minā ('As the gleam of the lightning feared the desires ') composed by the Sudanese author Muhammad b. Țāhir al-Mağdūb (1842-1929), a member of the Burhāniyya brotherhood. The text copied into the manuscript under discussion extends to the verse: Šafīu al-halqi fi ḥayratihim ('Intercessor of the creatures in their bewilderment').

28 I am here transcribing the phrase as it should be according to the rules of Classical Arabic: the transliteration system of Arabic used in the text is specifically analysed in part 3 of this chapter. 
- 7-13 November: hymn in honour of the Prophet; incipit: Al-ḥamd lillāh al-qadìm/ğalla rabbi 'an al-mitāal ('Praise to God the Eternal, my Lord is beyond any similarity');

- 14-21 November: another section of the above-mentioned poem Hāā al-'`ss adrik ka's al-hanā' ('O Camel Driver, get the chalice of happiness'); from the verse man arāda al-nağwa ('the one who wants the upland') to the end sayfuhu munșalitan mā wahana ('His sword is drawn and he is not weak');

- 21-22 November: the qașīda Bānat Su'ād ('Su'ād is gone', also called al-Burda 'The Mantel', like al-Bușīì's poem) by the famous Ka'b b. Zuhayr (first a fierce opponent of Muhammad, then one his Companions) with anonymous tahmis Hānat Su'ād (Su'ād arrived', up to the verse Hayfā' muqlatin 'ağzā' mudbiratin lā yuštakā qișarun minhā wa-lā țūl ('Thin appears when she comes and well-proportioned when she turns away, not too short nor too tall, no complaints about her height'); ${ }^{29}$

- 22 November-3 December: poem in honour of Abū Bakr (with tahmīs); incipit: Aya sā’ilì 'an madhi man ğalla fì al-dikr ('O the one who demands about the one who is honoured in the $\left.\operatorname{dikr}^{\prime}\right) ;^{30}$

- 4-5 December: poem in praise of 'Abd al-Qādir al-Ǧīlānī; incipit: 'Alā al-awliyā' alqaytu sirrī wa-burhānī ('On the saints I have thrown my secret and my proof'); ${ }^{31}$

- 6-7 December: poem in praise of 'Abd al-Qādir al-Ǧīlānī; incipit Yā quṭb al-wuğūd bi-kum șafā wuǧūdì ('O pole of the existence through you my existence is purified'); written in two columns; ${ }^{32}$

- 8-9 December: invocation to God; each verse starts with one different letter of the Arabic alphabet in our manuscript reproduced in a very coarse hand; incipit: Ilāhun wāḥidun munfaridun bi-dātih ('Only one God, alone in His essence'); ${ }^{33}$

- 10-13 December: poem in praise of the Prophet; incipit Salātun salāmun ka-miski al-hitām ('Prayer and greeting like the musk of the end'; attributed to 'Abdallāh Ibn 'Alawī al-Ḥaddād); ${ }^{34}$

- 13-15 December: poem in praise of the Prophet known from the Arabic-Harari refrain: Nūr salām nūr salām ('Light and greeting, light and greeting');

29 The bibliography about Ka'b and his Bānat Su'âd is extremely wide: see at least the article Sells and Sells 1990.

30 Mawlid edn 2005, 70-78.

31 Mawlid edn 2005, 100-101.

32 Mawlid edn 2005, 94-95.

33 Mawlid edn 2005, 98-99.

34 Mawlid edn 2005, 79-82. 
Arabic incipit: Šahidnā bi-annā Allāha zakkā Muḥammada ('We testify that God attested the truth of Muhammad'); $;^{35}$

- 15-18 December: poem in praise of the Prophet known from the Arabic-Harari refrain: $\bar{A} w$ ayo salām āw ayo salām ('Father, mother salute! Father, mother, salute!); Arabic incipit: Ğamālun badā min fawq al-'izzi dalla muḥtāğun fa-qāla hazzi ('A beauty appeared from above the high level a needy pointed out and said "Swing!"”); ${ }^{36}$

- 18-19 December: mystical poem; incipit: Bi-haqqi allāh riğāl allāh ('For God's sake, o men of God'); ${ }^{37}$

- 20-22 December: invocation; incipit: Habū lì min faḍlikum habū lì ('Grant me from your grace, grant me!');

- 24-29 December: hymn in praise of the Prophet; opening formula: Šay' lillāh rasūl allāh yā sayyidī habīb allāh al-madad rasūl allāh ('O dear to God, messenger of God! O my lord, beloved of God! Help, messenger of God!'); incipit: Abtadi'u bi-smi llāhi madḥa hayri halqi llāh ('I commence in the name of God the praise of the best of God's creatures'); ${ }^{38}$

- 4 September: prayer for the Prophet and šayh Abādir (the same as in 8-9 October); incipit: Șalātun wa-taslīmun wa-azkā tahyatin 'alā Aḥmad al-muhtār țaha al-mafähir ('Peace, greeting and best salutations to Ahmad, the chosen, the possessor of the glorious deeds'); tawassaltu bi-šayh al-Abādir ('I ask the intercession of šayh Abādir').

\section{Fidäl for Arabic: an easy adaptation?}

The relative proximity of the Arabic phonetic system to that of many of the Semitic languages of Ethiopia and Eritrea could generate the idea that the usage of fidäl to write Arabic might be a relatively simple adaptation process. I believe that the following few observations on the way Arabic has been transcribed in the manuscript under analysis only partially confirm this idea.

First of all, the linguistic interference represented in the manuscript is that between Arabic and Harari. To briefly highlight the main differences between the

35 Mawlid edn 2005, 62.

36 Mawlid edn 2005, 57-58.

37 Mawlid edn 2005, 52-54.

38 Mawlid edn 2005, 121-24. 
phonologies of these two languages, Wolf Leslau's contribution on the Arabic loanwords in Harari is useful as a reliable reference: ${ }^{39}$

Harari, on the one hand, possesses four phonemes which are absent in Arabic: a voiceless palato-alveolar affricate /č/; an 'emphatic' (ejective, glotta-

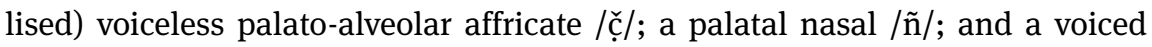
velar stop /g/. Arabic, on the other hand, has seven phonemes which do not exist in Harari: a voiceless (inter)dental fricative / $\mathrm{t} /$; a voiced (inter)dental fricative /d. $/$; an 'emphatic' (pharyngealised) voiced alveolar fricative /z//; an 'emphatic' (pharyngealised) voiceless alveolar fricative /ș/; an 'emphatic' (pharyngealised) voiced dental stop /d /; a voiced velar fricative / $\dot{\mathrm{g}} /$; and a voiced pharyngeal fricative $/ \%$

Moreover, there are four further important differences 1) the so-called 'emphatic' consonants are pronounced as ejectives (glottalised) in Harari, while they are basically pharyngealised in Arabic; 2) in Harari the voiceless velar fricative [h] appears only as an intervocalic variant of the voiceless velar stop / $\mathrm{k} /$ as a consequence of spirantisation and thus has no phonemic status. In Arabic loanwords, /h/ passes to / $\mathrm{k} /$ but is sometimes preserved; 3) Harari has a voiceless pharyngeal fricative $/ \mathrm{h} /$, but no voiceless glottal fricative $/ \mathrm{h} /$. Arabic $/ \mathrm{h} /$ is thus rendered as /h/ in Harari, but in some cases the original / $\mathrm{h} /$ is preserved; and, finally, 4) the vocalic system of Harari is still an object of discussion among linguists, but latest research points to the phonemic value of vowel quantity. ${ }^{40}$ It thus seems that in terms of both vowel quantity and vowel quality the phonology of Harari can easily accommodate Arabic words.

In the end, Leslau's analysis clearly demonstrates that the passage of a relatively substantial amount of Arabic loanwords (about 300) into Harari vocabulary did not take place according to a stable correspondence among phonemes of the two languages. The inconsistent phonetic adaptation is apparent when considering the way the Arabic phonemes (in particular those unknown to Harari) are rendered in Harari. ${ }^{41}$

It can be surmised that the picture is complicated by the fact that the Arabic loanwords' mode of entry into Harari is twofold: 1) oral, through one of the forms of spoken Arabic to which the speakers of Harari are exposed $;{ }^{42}$ and 2) written,

39 See Leslau 1956, and Leslau 1957, which contains a comprehensive description of the differences between the Arabic phonological system and that of other Semitic languages of the Horn of Africa.

40 For a detailed discussion on this, see Garad-Wagner 1998, 157-168, and for a more general description, see Wagner 1997, 487-488.

41 For the details, see in particular the recapitulative table in Leslau 1956, 21.

42 Leslau (1956, 22-23), indicates a number of Arabic dialects as possible sources for at least 
through a learned milieu, especially that of Arabic teachers and Islamic scholars who are well acquainted with the Classical Arabic of the Qur'an and the theological tradition. ${ }^{43}$

In the case of the manuscript I am presenting here, the issue of the Arabic dialects remaining behind or underneath the words is not relevant. Nevertheless, the idea that an oral dimension of the texts has influenced their transcription cannot be excluded from these considerations.

The main features of the transcription system used in the manuscript for depicting Arabic words in Ethiopian script can be briefly sketched as follows:

- voiceless (inter)dental fricative / $\mathrm{t} /$ : written as $\mathrm{n}<\mathrm{s}>$ for voiceless alveolar fricative /s/; e.g. n.n-l for tubūtu ('His immutability');

- $\quad$ voiced (inter)dental fricative / $/$ /: written as $\mathrm{H}\langle\mathrm{Z}\rangle$ for voiced alveolar fricative /z/; e.g. n.Ht:dh. for bi-datihi ('By His essence');

- 'emphatic' (pharyngealised) voiced alveolar fricative / $\mathrm{z} /$ : written as $\mathrm{H}<\mathrm{Z}>$ for voiced alveolar fricative /z/; e.g. Hihr for zahara ('It appeared');

- 'emphatic' (pharyngealised) voiceless alveolar fricative /ș/: written as ì <s> for voiceless alveolar fricative /s/; e.g. n.g.中'ı șidqun ('His truthfulness');

- 'emphatic' (pharyngealised) voiced dental stop /d /: written as $\mathbf{g}<\mathrm{d}>$ for (nonemphatic) voiced dental stop /d/; e.g. n.9\%: 1 for diyā'un ('Lights');

- voiced velar fricative / $\dot{\mathrm{g}} /$ : written as $\mathrm{h}<\mathrm{h}>$ for voiceless velar fricative / $\mathrm{h} /$, not only in intervocalic position but also in initial position; e.g. "int.9? for ganiyyun ('Rich');

- voiced pharyngeal fricative /‘/: written as h <’> for voiceless glottal stop /’/; e.g. ȟh.9? for'aliyyun ('Sublime');

- voiceless velar fricative / $h /$ : written as $\mathrm{h}<\mathrm{h}>$ for voiceless velar fricative / $\mathrm{h} /$, not only in intervocalic position but also in initial position; e.g. ne.t: for haraqtu ('I tore');

- voiceless pharyngeal fricative / $\mathrm{h} /$ and voiceless glottal fricative /h/: mostly both written as $\boldsymbol{h}<\mathrm{h}>$ for voiceless pharyngeal fricative / $\mathrm{h} /$; sometimes the Arabic voiceless glottal fricative $/ \mathrm{h} /$ is 'correctly' written as $\mathrm{U}<\mathrm{h}>$ with the

some of the Arabic loanwords in Harari, without being able to localise all of them in one single dialect. His conclusions are somewhat ambiguous. After remarking that 'one is inclined to think that not one single Arabic dialect is to be taken as the source of Harari, but various Arabic dialects', he says a few lines later: 'As for the historically possible source of the Arabic loanwords in Harari, a South Arabic dialect seems to be more likely to be considered'.

43 Leslau (1956) did not at all consider the possibility that at least some of the Arabic words he discusses could have entered Harari vocabulary from a learned, written source and not from a spoken variant of the language. An assessment of the loanwords taking this possibility into account might provide some fresh insights into the topic. 
Ethiopian letter for the voiceless glottal fricative /h/; however the letter U $<\mathrm{h}>$ is sometimes also used for rendering the voiceless pharyngeal fricative /h/ and vice versa; the Ethiopian letter $\mathrm{h}<\mathrm{h}>$ sometimes also represents $/ \mathrm{h} /$;

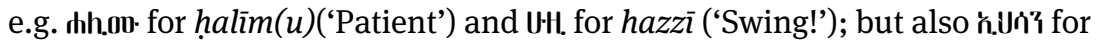
ihsān ('Doing good deeds') and Hhr for zahara ('He appeared').

The quality of the Arabic vowels /a/, /i/, / $\mathrm{u} /$ is always reproduced accordingly in the text in fidäl. As for quantity, only /ā/ is sometimes rendered with the fourth order of the Ethiopian syllabary $(<\mathrm{Ca}>)$, which in the orthography of modern Harari also represents the long $a$ (short /a/ written with the first order of the syl-

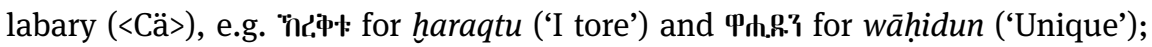
however the fourth order long /a/ can also be used for an Arabic short /a/, e.g. Hihr for zahara ('He appeared'). ${ }^{44}$ As for Arabic /i/ and / $\overline{\mathbf{1}} /$, both are always written with the third order of the Ethiopian syllabary $(<\mathrm{Ci}>)$, as well as $/ \mathrm{u} /$ and $/ \overline{\mathrm{u}} /$ being reproduced with the second order of the fidäl $(<\mathrm{Cu}>)$.

Diphthongs /aw/ and /ay/ are more or less consistently rendered in fidäl (e.g. h(t) for law ['If']), but many times the writing in fidäl seems to point to an assimilated pronunciation of the /a/ to the following /w/ or /y/ e.g. $9 \cdot(n) \cdot g$ yowm for yawm ('Day'), and 'n, heyr(u) for hayr(u) ('Benefit').

It is worth noting that in many instances the word division does not correspond to the one used in Arabic; thus forms like n.Ht:h. for bi-datihi ('By His

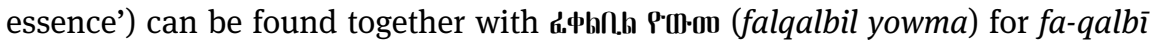
al-yawma ('Then my heart today').

To sum up the collected data, the rendering of the Arabic texts in fidäl can be considered as being only partially accurate. Failure to represent many Arabic phonemes makes the transcription to a great extent imprecise: it is true that the Ethiopian syllabary lacks specific signs for some of the Arabic phonemes and for distinguishing the vowel quantity of $/ \mathrm{i} /$ and $/ \mathrm{u} /$, but no creative effort has been made by the copyist to fill the gaps in the writing system he was using and create a one-to-one sign set of transliteration.

The written rendering in fidäl of many of the Arabic sounds which are absent in Harari follows the same pattern as the phonetic adaptation of the Arabic loanwords into Harari. The word division in Ethiopian script is quite inconsistent and often only oddly corresponds to the Arabic original. The diphthongs are written in a way that hints at an assimilation of the short Arabic /a/ to the following semi consonant.

44 See Wagner 2004, 358-359 for a discussion of the treatment of the vowels in the fidäl orthography of Harari. 
These elements possibly indicate that the writing process of the manuscript was carried out while hearing someone from Harar reciting the texts or while the copyist himself was reading them aloud. As a matter of fact, the writing down of the Arabic texts does not adhere to any written model: the copyist does not even try to rewrite in fidäl a written Arabic Vorlage, but mostly transcribes the texts the way they would sound, if they were read by a Harari speaker. The copyist does not seem to have any intention to produce a well-thought-out system of transliteration of Arabic with the Ethiopian syllabary, he just aims at providing the faithful who are unfamiliar with Arabic script with a tool to access the texts and recite them on different religious occasions. ${ }^{45}$

To my knowledge this is so far the only known example of a substantial amount of complex Arabic texts written in Ethiopian syllabary. The general cultural trends in the Islamic communities in Ethiopia will tell us whether it will remain only an individual, isolated effort or the first step of a linguistic and literary development among the Ethiopian Muslims.

\section{References}

Abdurahman Mäḥamäd Qorram (1984 Ethiopian Calendar = 1992), C̣uqti katab. Yä'adäraññaamarə̃̃̃̃a mäzgäbä qalat, Addis Ababa.

Banti, Giorgio (2005), 'Harari literature', in Siegbert Uhlig (ed), Encyclopaedia Aethiopica, vol II (D-Ha), Wiesbaden: Otto Harrasowitz Verlag, 1028-1030.

Banti, Giorgio (2010), 'The literature of Harar until the end of the 19th century', in Alessandro Gori and Biancamaria Scarcia Amoretti (eds), Islam in Etiopia: bilanci e prospettive. Atti del Convegno Internazionale. Università degli Studi di Napoli Federico II, 18-19 giugno 2008 (Civiltà del Mediterraneo, 16-17), Roma: Edizioni di Storia e Letteratura, 149-181.

Bausani, Alessandro (1967), 'Per una lettura comparata delle lingue islamiche', in Atti del Terzo Congresso di Studi Arabi e Islamici, Ravello, 1-6 settembre 1966, Napoli: Istituto Universitario Orientale, $145-56$.

Bausani, Alessandro (1978), 'Incontri linguistici in Asia: esperienze di un orientalista', in Lingue a contatto nel mondo antico. Atti del Convegno della Società Italiana di Glottologia, Napoli, 12 e 13 maggio 1978 (Orientamenti Linguistici, 7), Pisa: Giardini, 11-33.

45 The usage of somewhat impressionistic transcriptions of Arabic religious texts based on a phonetically very imprecise oral reproduction of Arabic to meet the needs of the common faithful who do not read Arabic is very common in all non-Arabic speaking Islamic countries. See for example the dozens of different booklets for the performance of the ritual prayers in use in Turkey (commonly referred to as namaz hocası) which contain Arabic texts written in Latin script according to current Turkish pronunciation of Arabic (e.g. Elhamdulillâhillezî ce'alel-mâe tahûren ve ce'alel-İslâme nûra). 
Bausani, Alessandro (1981), 'Le lingue islamiche: interazioni e acculturazioni’, in Alessandro Bausani and Biancamaria Scarcia Amoretti (eds), Il mondo islamico tra interazione e acculturazione, Roma: Istituto di Studi Islamici, 3-19.

Brenner, Louis, and Murray Last (1985), 'The Role of Language in West African Islam' in Africa: Journal of the International African Institute, 55: 432-446.

Cerulli, Enrico (1926), 'Canti amarici dei musulmani d'Abissinia', in Accademia Nazionale dei Lincei. Rendiconti serie VI, II: 433-447 (reprinted in Cerulli, Enrico. 1971, L'islam di ieri e di oggi, Roma: Istituto per l'Oriente, 245-256).

Conti Rossini, Carlo (1919), 'Testi in lingua harari', in Rivista degli Studi Orientali, 8: 401-425.

Donzel, Emeri Johannes van (ed. and tr.) (1969), 'Énbaqom: Anqasa Amin (La porte de la foi), apologie éthiopienne du Christianisme contre lilslam à partir du Coran. Leiden: E. J. Brill.

Frantsouzoff, Serguei A., (2010), 'Script, Ethiopic', in Siegbert Uhlig and Alessandro Bausi (eds), Encyclopaedia Aethiopica, vol. IV (O-X), Wiesbaden: Otto Harrassowitz Verlag, 580-585.

Garad, Abdurahman, and Ewald Wagner (1998), Harari-Studien. Texte mit Übersetzung und grammatischen Skizzen und Glossar, Wiesbaden: Otto Harrassowitz Verlag.

Gibb, Camilla (1998), 'Religious Identification in Transnational Contexts: Being and Becoming Muslim in Ethiopia and Canada', in Diaspora: A Journal of Transnational Studies, 7: 247-269.

Gibb, Camilla (2002), 'Deterritorialized People in Hyperspace: Creating and Debating Harari Identity over the Internet', in Anthropologica, 44: 55-67.

al-Ǧīlānī, 'Abd al-Qādir, (s.d.), Dīwān 'Abd al-Qādir al-Ǧīlānī, edited by Yūsuf Zaydān, Bayrūt: Dār al-Ǧìl.

Gori, Alessandro (2001), La 'Silloge' di šah Zakkāryās. Testo arabo originale, introduzione traduzione e note di Alessandro Gori (Accademia Nazionale dei Lincei, Atti, Classe di Scienze morali, storiche e filologiche, Memorie. Scienze morali, storiche, filologiche, serie 9, 13, 4: 453-583), Roma: Accademia Nazionale dei Lincei.

Gori, Alessandro (2003), La 'Silloge' di šah Zakkāryās sull'Islam - Versione amarica. Testo amarico originale, introduzione, traduzione e note di Alessandro Gori (Accademia Nazionale dei Lincei, Atti, Classe di Scienze morali, storiche e filologiche, Memorie. Scienze morali, storiche, filologiche, serie 9, 16, 2: 57-319), Roma: Accademia Nazionale dei Lincei.

Gori, Alessandro (2010), 'Texts in the Mawlid Collection in Harar: some first critical observations', in African Study Monographs, Supplement 41: 51-62.

Gori, Alessandro (2014a), 'Zäkaryas', in Alessandro Bausi and Siegbert Uhlig (eds), Encyclopaedia Aethiopica, vol. V (Y-Z), Wiesbaden: Otto Harrassowitz Verlag, 116-117.

Gori, Alessandro (2014b), Ağamī in the opposite way. An Arabic manuscript text written in Ethiopian script (EMML 6239). Unpublished presentation delivered at the Colloque Manuscrits chrétiens et islamiques d'Ethiopie (XIIIe-XXe siècle) 12-13 December 2014, Bibliothèque nationale de France, Paris.

Gori, Alessandro (2015), 'Languages and literatures of the Muslims of the Horn of Africa: some first general reflections', in Paolo Nicelli (ed.), L'Africa, l'Oriente mediterraneo e l'Europa: tradizioni e culture a confront (Africana Ambrosiana, 1), Milano, Roma: Biblioteca Ambrosiana - Bulzoni Editore, 119-126.

Gori, Alessandro, Anne Regourd, Jeremy Brown, Steve Delamarter, and Demeke Berhane (2014), A Handlist of the Manuscripts in the Institute of Ethiopian Studies, Volume Two: The Arabic 
Materials of the Ethiopian Islamic Tradition, (= Ethiopic manuscripts, texts and studies, 20). Eugene, Or.: Pickwick Publications.

Griaule, Marcel (1930), Le livre de recettes d'un dabtara abyssin, (= Travaux et mémoires de l'institut d'ethnologie, XII). Paris: Institut d'ethnologie.

Leslau, Wolf (1956), 'Arabic Loanwords in Harari', in Studi Orientalistici in Onore di Giorgio Levi Della Vida, Vol. II, Roma: Istituto per l'Oriente. 14-35 (reprinted in Leslau, Wolf (1990), Arabic Loanwords in Ethiopian Semitic, Wiesbaden: Otto Harrassowitz Verlag, 119-140). Leslau, Wolf (1957), 'The Phonetic Treatment of the Arabic Loanwords in Ethiopic', in Word, 13: 100-23 (reprinted in Leslau, Wolf (1990), Arabic Loanwords in Ethiopian Semitic, Wiesbaden: Otto Harrassowitz Verlag, 213-236).

Mawlid (2005), Kitāb mawlid šaraf al-‘ālamīn. Edited by Abū Bakr T̄ābit (Sabit), Addis Ababa: Dire Printing S.C.

Mittwoch, Eugen (1906), 'Exzerpte aus dem Koran in amharischer Sprache', in Mitteilungen des Seminars für Orientalischen Sprachen zu Berlin, 9: 111-147.

Pietruschka, Ute, Amha Asfaw, and Getatchew Haile (2003), 'Baḥrä ḥassab', in Siegbert Uhlig (ed.), Encyclopaedia Aethiopica, vol. I (A-C), Wiesbaden, Otto Harrassowitz Verlag, 445-446.

Sells, Michael Anthony - Sells, M. J. (1990), “Bānat Su'ād': Translation and Introduction', in Journal of Arabic Literature, 21/2:140-154.

Wagner, Ewald (1997), 'Harari', in Robert Hetzron (ed.), The Semitic Languages, Abingdon, New York: Routledge, 486-508.

Wagner, Ewald (2003a), Harar: Annotierte Bibliographie zum Schrifttum über die Stadt und den Islam in Südostäthiopien (Aethiopistische Forschungen, 61), Wiesbaden: Otto Harrassowitz Verlag.

Wagner, Ewald (2003b), 'Abādir 'Umar ar-Riḍā', in Siegbert Uhlig (ed.), Encyclopaedia Aethiopica, vol. I (A-C), Wiesbaden: Otto Harrassowitz Verlag, 4-5.

Wagner, Ewald (2004), 'Die Verwendung der äthiopischen Schrift für das Harari', in Verena Böll, Denis Nosnitsin, Thomas Rave, Wolbert Smidt, and Evgenia Sokolinskaia (eds), Studia Aethiopica: In Honour of Siegbert Uhlig on Occasion of His 65th Birthday, Wiesbaden: Otto Harrassowitz Verlag, 355-360.

Wagner, Ewald (2005), 'Farā’iḍ, Kitāb al-', in Siegbert Uhlig (ed.), Encyclopaedia Aethiopica, vol II (D-Ha), Wiesbaden: Otto Harrassowitz Verlag, 491-492.

Zappa, Francesco (2004), L'islamizzazione della lingua bambara in Mali. Tra pubblicistica scritta e letteratura orale (= Supplemento n. 2 della Rivista degli Studi Orientali, vol. LXXVII), Pisa/Roma: Istituti Editoriali e Poligrafici Internazionali.

Zappa, Francesco (2009), 'Écrire l'Islam en Bambara', in Archives de sciences sociales des religions, $147:$ 167-186. 